\title{
Potential for omnivory and apparent intraguild predation in rocky intertidal herbivore assemblages from northern Chile
}

\author{
Patricio A. Camus ${ }^{1,2, *}$, Karen Daroch ${ }^{1}$, L. Felipe Opazo ${ }^{1}$ \\ ${ }^{1}$ Departamento de Ecología Costera, Facultad de Ciencias, Universidad Católica de la Ssma. Concepción, PO Box 297, \\ Concepción, Chile \\ ${ }^{2}$ Center for Advanced Studies in Ecology and Biodiversity, P. Universidad Católica de Chile, Santiago, Chile
}

\begin{abstract}
We assessed the ingestion of animal items by 29 herbivore species of the most common invertebrates on rocky intertidal shores of northern Chile $\left(21\right.$ to $\left.30^{\circ} \mathrm{S}\right)$. Data were obtained from 4 communities sampled seasonally from winter 2004 to spring 2005. Gastric contents of 2671 individuals were categorized into 143 food items, $42.7 \%$ of them corresponding to animal prey. All herbivores were polyphagous generalists, showing a moderate to high dietary overlap and suggesting the potential for exploitation competition. Diet width and the proportion of animal items ingested per species were positively related with body mass, revealing a high potential for true omnivory among larger herbivores. Barnacles were the dominant prey item, followed by a suite of common intertidal animals, including herbivore species. The consumption of herbivores was defined as apparent intraguild (IG) predation, a framework that we used by analogy to describe pairwise interactions at a regional and community level. We recorded 29 IG predator-IG prey interactions, all of them asymmetrical (no reciprocal predation), and directed exclusively towards heterospecific IG prey, which in most cases were juvenile individuals that were taxonomically unrelated. All IG predators were large herbivore species, and they appeared to avoid consuming conspecifics. The high incidence of polyphagy and apparent IG predation may not be simply an epiphenomenon of grazing, nor a response to limited algal resources, and we discuss the nature of herbivores as consumers and the implications of potential omnivory for the connectedness, looping, and chain length of intertidal food webs.
\end{abstract}

KEY WORDS: Herbivory $\cdot$ Diet $\cdot$ Niche breadth $\cdot$ Polyphagy $\cdot$ Connectivity $\cdot$ Food web

\section{INTRODUCTION}

Herbivorous invertebrates and their food preferences are long recognized to play a key role in the functioning of rocky intertidal systems (Lubchenco 1978, Lubchenco \& Gaines 1981). However, herbivores continue to be less studied than carnivores with regard to their nature as consumers and their trophic status within community food webs. Nearly 3 decades ago, Lubchenco (1979) proposed that both herbivorous and carnivorous consumers should be termed predators, because they played an equivalent functional role in terms of predator-prey dynamics. Although this issue has not received much attention in the marine literature, there are several reasons why it deserves further examination. Many species traditionally considered to be herbivores regularly ingest invertebrate animals in direct or indirect ways (e.g. Santelices \& Correa 1985, Wootton 1993, Hughes et al. 2005), raising the question whether they are true herbivores or are actually omnivores. However, proper assessments of the assimilation of ingested food items are rather infrequent in dietary and food web analyses, and the determinations of energy flows and even the trophic level of species are not always clear (Williams \& Martinez 2004). Thus, the importance of non-algal food resources to herbivores 
remains poorly understood (Briscoe \& Sebens 1988), as is the trophic status of these consumers. Such herbivores could be treated as omnivores in a wide sense (eating plants and animals), but they may also fit particular definitions of omnivory (some not too suitable for herbivores), such as feeding on more than one trophic level (Pimm \& Lawton 1978), being linked to a basal species at more than one link in a trophic chain (Yodzis 1984), or eating basal (plant) and intermediate (animal) species (Arim \& Marquet 2004). The latter two may apply to the special case of herbivores that eat other herbivores, which are the focus of the present work, and represents a 3-level food chain with a 'predator' herbivore consuming a 'prey' herbivore feeding on basal species, i.e. an omnivore link (sensu Yodzis 1984). In addition, if 'predator' and 'prey' herbivores share and potentially compete for algal prey, the omnivore link turns into a closed omnivore loop (sensu Sprules \& Bowerman 1988), placing their interaction into the domain of intraguild predation (Polis et al. 1989, Polis \& Holt 1992). Thus, intraguild predation among rocky intertidal invertebrate herbivores appears to be an intriguing possibility, which partly turns back to Lubchenco's (1979) suggestion about the functional similarity of herbivores and carnivores acting as predators. Analysis of intraguild predation in rocky or estuarine intertidal systems (e.g. Navarrete et al. 2000, Omori et al. 2006) certainly deals with carnivorous or omnivorous predators, but we suggest that an analogous approach for herbivorous consumers may provide some useful insights. On rocky shores, the incidental consumption of herbivores by herbivores is a real phenomenon that, at first instance, we might term 'apparent' intraguild predation. It has a direct negative effect on 'prey' abundance, and even if the 'predator' does not feed on the prey (i.e. receives no direct gain of energy or nutrients), both herbivores may indirectly benefit from a potential reduction of exploitative competition, an outcome similar to that expected from true intraguild predation (Polis et al. 1989).

In this context, we present a first assessment of the consumption of animal items and apparent intraguild predation in invertebrate herbivore assemblages from northern Chile, integrating dietary information from seasonal samplings conducted over one and a half years in 4 rocky intertidal communities. In this regard, we treat herbivore 'prey' and 'predators' in analogous terms to those proposed by Polis et al. (1989) for intraguild predation. All herbivore species in the present study included some fraction of animal items in their diet, thus being polyphagous and potential omnivores in a wide sense or under Pimm \& Lawton's (1978) definition. However, at least a third of these species included other herbivores in their animal diet and shared algal prey to various extents, thus also being potential competitors engaged in closed omnivore loops. Thus, our herbivore food web differentiates organisms into herbivores eating non-herbivorous animals, which may be intraguild prey but not intraguild predators, and those eating other herbivores, which may be either intraguild predators or intraguild prey (if they are in turn consumed by another intraguild predator). Therefore, 'prey' herbivores are treated as species of intermediate trophic position between basal species and 'predator' herbivores, while these latter are treated as omnivores following Yodzis (1984) and Arim \& Marquet (2004).

\section{MATERIALS AND METHODS}

Sampling and diet evaluation. From winter 2004 to spring 2005, we sampled 4 rocky intertidal communities distributed over $\sim 1000 \mathrm{~km}$ of coast in northern Chile (Fig. 1): Río Seco (hereafter, RIO; $21^{\circ} 00^{\prime} 05^{\prime \prime} \mathrm{S}$, $\left.70^{\circ} 09^{\prime} 54^{\prime \prime} \mathrm{W}\right)$, Caleta Constitución (CCO; $23^{\circ} 25^{\prime} 23^{\prime \prime} \mathrm{S}$, $\left.70^{\circ} 35^{\prime} 26^{\prime \prime} \mathrm{W}\right)$, Caleta Angosta (CAN; $28^{\circ} 15^{\prime} 38^{\prime \prime} \mathrm{S}$, $71^{\circ} 10^{\prime} 23^{\prime \prime} \mathrm{W}$ ), and Lagunillas (LAG; $30^{\circ} 06^{\prime} 14^{\prime \prime} \mathrm{S}$, $\left.71^{\circ} 22^{\prime} 57^{\prime \prime} \mathrm{W}\right)$. The 4 sites differ in their local upwelling regimes, as CCO and LAG are known to be influenced by important upwelling centers throughout the year (Vásquez et al. 1998, Thiel et al. 2007). In the present paper we include samplings from 6 austral seasons: winter 2004 (August 15 to 27), spring 2004 (November 8 to 16), summer 2005 (January 20 to 27), autumn 2005 (May 22 to June 1), winter 2005 (August 18 to 25), and spring 2005 (November 8 to 16). The presence and

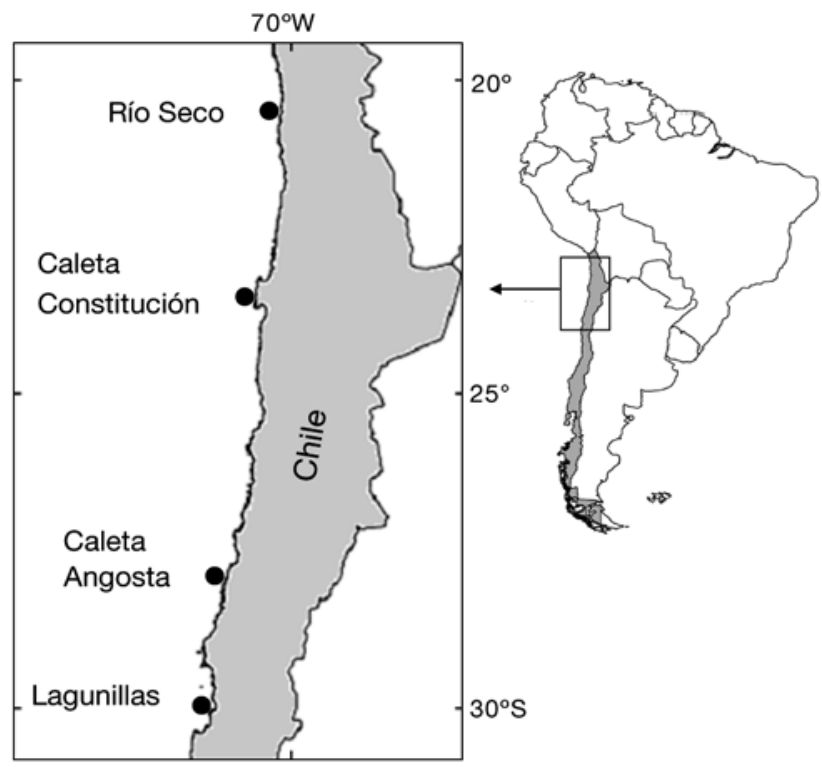

Fig. 1. Location of rocky intertidal sites sampled along the coast of northern Chile 
abundance of herbivores were recorded in 45 quadrats $\left(0.25 \mathrm{~m}^{2}\right)$ assigned to 15 transects distributed into 5 permanent sampling blocks, and stratified by intertidal zone (high, mid, low), covering ca. $130 \mathrm{~m}$ of coastline. As herbivores differ in vertical distribution, density was calculated from those quadrats where each species occurred (mean \pm SE sample size $=125.6 \pm 4.6$ ). At each site and season, herbivorous individuals were collected at different tidal heights from the 5 sampling blocks, in order to incorporate the environmental patchiness of their food resources. Based on previous estimations, we planned to collect 10 individuals per season of each of the most conspicuous herbivorous species at each site, representing 85 to $100 \%$ of the food items locally consumed through all seasons by nearly $90 \%$ of the studied species, which is similar to reports by other authors (e.g. Winemiller et al. 2001). Actual sample sizes varied depending on the natural occurrence of species, and the average $( \pm \mathrm{SE})$ number of individuals collected per species, community, and season were $8.9 \pm 0.9(\mathrm{RIO}), 9.7 \pm 0.7(\mathrm{CCO}), 8.8 \pm 0.8$ $(\mathrm{CAN})$, and $8.5 \pm 1.1(\mathrm{LAG})$.

Maximum body length and dry biomass (oven dried to constant weight at $70^{\circ} \mathrm{C}$ ) were recorded for each sampled individual, and its intestinal content was analyzed under a stereoscopic microscope to determine the identity of dietary items to the lowest possible taxonomic level. While some identification problems were inevitable, our estimations have, to our best knowledge, the highest taxonomic resolution among dietary studies so far conducted in Chilean intertidal communities. Because most herbivores rasp or scrape their food, their intestinal contents were composed mainly of body parts or tissue fragments, preventing abundance counts and estimations of prey body size. We therefore treated food as a niche dimension of discrete resource states involving the type, number, and frequency of occurrence of consumed food items (note that these values may not indicate gravimetric or numeric importance, and they are not intended to reflect interaction strength in terms of per capita effects). As a complementary estimation, for each of 18 of the most important herbivore species, we measured the total biomass of algal and animal contents in the entire gastric system of 3 individuals per species, calculating their respective proportions (\%). On this basis, we also provide a simple estimation of the biomass per algal and animal item per species as the quotient between (algal and animal) biomass, and the average number of (algal and animal) dietary items recorded for all individuals of each species (note that this approximation may vary in field individuals depending on their degree of gastric fullness).

Trophic relationships. Across the 4 communities, we calculated: (1) the mean niche breadth of each herbi- vore species (after Levins 1968), measured by an index integrating both the number and the relative frequency of resource states (trophic items) used by the species (Feinsinger et al. 1981), and expressed as the average of breadth values recorded in the 4 localities, and (2) the mean niche overlap (after Pianka 1973) of each herbivore species with the remaining herbivores, measured by an index providing a pairwise estimation of the extent to which trophic items were shared between 2 herbivore species, and expressed as the average of overlap values obtained for a given herbivore. We then identified all herbivorous individuals that consumed another herbivorous individual, in order to establish the potential pairwise interactions among species and their relative importance in quantitative terms. Due to the low occurrence of herbivorous individuals among non-algal dietary items, we pooled data to assess intraguild predation (IGP) in 2 different ways. At the community level, we combined seasonal data to calculate the occurrence frequency of 'prey' herbivore species within each pairwise interaction, i.e. the proportion of the total number of individuals of each 'predator' herbivore that consumed a given 'prey' herbivore. For simplicity, we hereafter refer to these as IG predator and IG prey, respectively. For each community, the observed predator-prey links were represented as simple web diagrams showing the relative trophic position of the species. Although we lacked quantitative data on the abundance and body size of IG prey in intestinal contents, we kept qualitative records of their size to provide information about ontogenetic stage (juvenile vs. adult). At a regional level, we combined all available data to summarize the observed pairwise interactions. For each interaction, we provide: (1) the mean dietary overlap between IG predator and IG prey at the adult stage, to indicate the potential for exploitation competition; (2) two separate estimates of their body size ratio (IG predator/IG prey), based on the mean maximum length and mean dry biomass of all individuals sampled per species, to describe the symmetry of their adult sizes (i.e. not considering the size of consumed IG prey); (3) the mean dietary breadth of IG predators; (4) the total number of sampled IG predator individuals; and (5) the overall frequency of occurrence of IG prey.

\section{RESULTS}

\section{Consumption of animal food items}

We analyzed 2671 herbivorous individuals belonging to 29 species of Mollusca, Echinodermata, and Crustacea, with field densities ranging from 4.5 to 313 individuals $\mathrm{m}^{-2}$ (Table 1 ). These species showed 
Table 1. Herbivorous species collected during 6 seasonal samplings (winter 2004 to spring 2005) in 4 rocky intertidal communities from northern Chile. Family and abbreviated class (P: Polyplacophora; G: Gastropoda; C: Crustacea; E: Echinoidea). NC: number of communities where the species occurred; PS: percentage of samples where the species was present (total $=24$ community $\times$ season samples); TN: total number of algal + animal items; NA: number and proportion ( $\mathrm{P}$, in \%) of animal items; $\mathrm{D}$ : density (mean $\pm \mathrm{SE}$; individuals $\mathrm{m}^{-2}$ ); na: data not available

\begin{tabular}{|c|c|c|c|c|c|c|}
\hline Species & Family, class & $\mathrm{NC}$ & PS & $\mathrm{TN}$ & NA $(P)$ & $\mathrm{D}$ \\
\hline Acanthopleura echinata (Barnes) & Chitonide, $\mathrm{P}$ & 4 & 70.8 & 89 & $33(37.1)$ & $6.83 \pm 0.46$ \\
\hline Chiton cumingii Frembly & Chitonide, $\mathrm{P}$ & 1 & 4.2 & 21 & $6(28.6)$ & $10.46 \pm 5.81$ \\
\hline Chiton granosus Frembly & Chitonide, $\mathrm{P}$ & 4 & 75 & 62 & 19 (30.6) & $7.36 \pm 0.52$ \\
\hline Chiton magnificus Deshayes & Chitonide, $\mathrm{P}$ & 1 & 4.2 & 37 & $8(21.6)$ & $6.80 \pm 2.07$ \\
\hline Enoplochiton niger (Barnes) & Chitonide, $\mathrm{P}$ & 4 & 100 & 94 & $35(37.2)$ & $10.20 \pm 0.69$ \\
\hline Tonicia elegans Frembly & Chitonide, $\mathrm{P}$ & 3 & 12.5 & 25 & $4(16.0)$ & $4.50 \pm 0.50$ \\
\hline Fissurella costata Lesson & Fissurellidae, G & 2 & 16.7 & 33 & $5(15.2)$ & na \\
\hline Fissurella crassa Lamarck & Fissurellidae, G & 4 & 87.5 & 87 & $28(32.2)$ & $5.63 \pm 0.29$ \\
\hline Fissurella limbata Sowerby & Fissurellidae, G & 4 & 33.3 & 87 & $32(36.8)$ & $5.55 \pm 0.37$ \\
\hline Fissurella maxima Sowerby & Fissurellidae, G & 4 & 62.5 & 83 & $30(36.1)$ & $5.74 \pm 0.33$ \\
\hline Fissurella nigra Lesson & Fissurellidae, G & 2 & 8.3 & 42 & $8(19.0)$ & $6.00 \pm 2.00$ \\
\hline Fissurella picta (Gmelin) & Fissurellidae, G & 4 & 41.7 & 67 & $20(29.9)$ & $5.52 \pm 0.42$ \\
\hline Lottia orbigny Dall & Lottiidae, G & 1 & 4.2 & 11 & $1(9.1)$ & $10.29 \pm 2.04$ \\
\hline Scurria araucana (Orbigny) & Lottiidae, G & 4 & 75 & 49 & $10(20.4)$ & $11.39 \pm 0.66$ \\
\hline Scurria ceciliana (Orbigny) & Lottiidae, G & 3 & 29.2 & 31 & $8(25.8)$ & $36.97 \pm 3.88$ \\
\hline Scurria plana (Philippi) & Lottiidae, G & 1 & 4.2 & 29 & $7(24.1)$ & $7.08 \pm 0.97$ \\
\hline Scurria scurra (Lesson) & Lottiidae, G & 1 & 4.2 & 7 & $1(14.3)$ & na \\
\hline Scurria variabilis (Sowerby) & Lottiidae, G & 4 & 16.7 & 30 & $4(13.3)$ & $7.10 \pm 0.53$ \\
\hline Scurria viridula (Lamarck) & Lottiidae, G & 4 & 83.3 & 55 & $16(29.1)$ & $7.32 \pm 0.58$ \\
\hline Scurria zebrina (Lesson) & Lottiidae, G & 3 & 12.5 & 25 & $7(28.0)$ & $8.69 \pm 0.96$ \\
\hline Onchidella marginata (Gould) & Onchidiidae, G & 1 & 4.2 & 15 & $2(13.3)$ & $10.86 \pm 6.22$ \\
\hline Siphonaria lessoni (Blainville) & Siphonariidae, G & 3 & 66.7 & 44 & $10(22.7)$ & $15.88 \pm 1.18$ \\
\hline Diloma nigerrima (Gmelin) & Trochidae, G & 2 & 8.3 & 10 & $3(30.0)$ & $5.14 \pm 0.74$ \\
\hline Tegula atra (Lesson) & Trochidae, G & 4 & 91.7 & 63 & $17(27.0)$ & $241.78 \pm 28.18$ \\
\hline Tegula tridentata (Potiez \& Michaud) & Trochidae, G & 3 & 12.5 & 23 & $6(26.1)$ & $6.35 \pm 0.70$ \\
\hline Prisogaster niger (Wood) & Turbinidae, G & 3 & 50 & 33 & $9(27.3)$ & $313.64 \pm 41.73$ \\
\hline Taliepus dentatus (Milne Edwards) & Majidae, C & 1 & 4.2 & 30 & $7(23.3)$ & $7.00 \pm 1.96$ \\
\hline Loxechinus albus Molina & Echinidae, E & 4 & 16.7 & 86 & $29(33.7)$ & $11.62 \pm 1.18$ \\
\hline Tetrapygus niger Molina & Arbacidae, E & 4 & 100 & 99 & 34 (34.3) & $20.87 \pm 1.72$ \\
\hline
\end{tabular}

an average occurrence of ca. $70 \%$ in the study communities and ca. $40 \%$ in the 24 samples of communities by seasons, and the assemblage was composed mainly of patellogastropod limpets (Lottiidae), keyhole limpets (Fisurellidae), and chitons (Chitonidae) (Table 1). The herbivore assemblage consumed a total number of 143 dietary items, from which 82 corresponded to algae determined to different taxonomic levels (46 species, 32 genus, 1 family, and 3 groupings). On the whole, the 2671 individuals ingested a total number of 2893 animal prey (sessile and mobile invertebrates), categorized into 61 items, representing $>40 \%$ of the total number of dietary items. At the species level, the total number of consumed items ranged from 7 to 99 , with an average $( \pm \mathrm{SE})$ of $48.2 \pm 5.1$ items species ${ }^{-1}$, while the proportion of animal items ranged from 9.1 to $37.2 \%$, with an average $( \pm \mathrm{SE})$ of $26.2 \pm 1.4 \%$ species $^{-1}$. In addition, body size (mean dry biomass) of herbivore species was positively related with the total number of dietary items (Pearson's $r=0.66, p<0.001, n=29$ ) and the proportion of animal items (Pearson's $r=0.50, p=$ $0.006, \mathrm{n}=29$ ). We also note that, in particular seasons, the proportion of animals ingested by larger herbivores could be higher than the overall estimates in Table 1, for example, up to $82 \%$ in Fissurella limbata, $66 \%$ in F. maxima, $60 \%$ in Acanthopleura echinata, $49 \%$ in Enoplochiton niger, $44 \%$ in Tetrapygus niger, and $41 \%$ in F. crassa.

Table 2 shows the animal items ingested by the herbivore assemblage, and their frequency of occurrence with respect to the number of herbivorous individuals analyzed both for northern Chile on the whole and for each community. The occurrence of the main items (frequency $\geq 1 \%$ ) was highly consistent and did not show significant differences among the 4 study communities $\left(\chi^{2}=58.81, \mathrm{p}=0.081, \mathrm{df}=45\right)$. From the 29 herbivore species, 13 occurred as IG prey and were consumed by $1.77 \%$ of the sampled individuals (see Table 4 for a separate analysis of IG prey). In contrast, barnacles were by far the most important animal items, and overall they were consumed by $54.8 \%$ of the herbivorous individuals. Barnacle items included larvae and undetermined remains (plates and body parts), plus 5 identified species (Table 2), which, in some 
Table 2. Occurrence frequency (\%) of animal items ingested by individuals of species listed in Table 1, calculated for northern Chile (Regional) and for each community (RIO: Río Seco; CCO: Caleta Constitución; CAN: Caleta Angosta; LAG: Lagunillas). Higher taxa abbreviated as A: Aracnida; AM: Amphipoda; AN: Anthozoa; B: Bivalvia; CI: Cirripedia; CR: Crustacea;

D: Decapoda; G: Gastropoda; I: Insecta; P: Polychaeta; ni: not identified to species or genus level

\begin{tabular}{|c|c|c|c|c|c|}
\hline Animal item & $\begin{array}{c}\text { Regional } \\
(\mathrm{n}=2671)\end{array}$ & $\begin{array}{c}\text { RIO } \\
(\mathrm{n}=697)\end{array}$ & $\begin{array}{c}\mathrm{CCO} \\
(\mathrm{n}=651)\end{array}$ & $\begin{array}{c}\text { CAN } \\
(\mathrm{n}=654)\end{array}$ & $\begin{array}{c}\text { LAG } \\
(\mathrm{n}=669)\end{array}$ \\
\hline Barnacle remains, CI & 42.33 & 53.66 & 45.01 & 33.03 & 38.42 \\
\hline Foraminifera & 5.94 & 9.90 & 2.46 & 4.89 & 6.43 \\
\hline Notochthamalus scabrosus (Darwin), CI & 5.57 & 7.32 & 1.84 & 2.60 & 10.46 \\
\hline Hyale sp., CR & 5.46 & 8.18 & 6.30 & 2.60 & 4.78 \\
\hline Jehlius cirratus (Darwin), CI & 5.27 & 9.61 & 4.15 & 1.53 & 5.68 \\
\hline Bryozoa, ni & 5.09 & 6.60 & 2.92 & 5.50 & 5.38 \\
\hline Hydrozoa, ni & 4.12 & 3.01 & 5.53 & 1.53 & 6.58 \\
\hline Liopetrolisthes mitra (Dana), D & 4.05 & 3.87 & 3.99 & 3.21 & 5.23 \\
\hline Semimytilus algosus (Gould), B & 3.94 & 9.90 & 1.08 & 2.14 & 2.39 \\
\hline Nematoda, ni & 3.90 & 3.30 & 3.69 & 5.20 & 3.59 \\
\hline Austrolittorina araucana (Orbigny), G & 3.86 & 9.04 & 1.54 & 3.52 & 1.20 \\
\hline Perumytilus purpuratus (Lamarck), G & 3.19 & 7.46 & 0.92 & 1.83 & 2.39 \\
\hline Herbivore IG prey (13 species; see Table 4 ) & 1.77 & 3.4 & 1.05 & 0.9 & 1.65 \\
\hline Ostracoda, ni & 1.37 & 0.00 & 0.00 & 0.15 & 5.38 \\
\hline Spirorbidae, ni - P & 1.23 & 0.57 & 0.31 & 1.99 & 2.09 \\
\hline Dipteran larvae, ni - I & 1.19 & 0.72 & 0.92 & 1.68 & 1.49 \\
\hline Acari, ni - A & 1.19 & 0.57 & 1.23 & 1.07 & 1.94 \\
\hline Polychaeta, ni & 1.00 & 1.43 & 0.77 & 0.92 & 0.90 \\
\hline Tardigrada, ni & 0.97 & 1.58 & 0.92 & 0.92 & 0.45 \\
\hline Isopoda, ni & 0.71 & 1.00 & 0.46 & 0.76 & 0.60 \\
\hline Notobalanus flosculus (Darwin), CI & 0.67 & 1.29 & 0.15 & 0.31 & 0.90 \\
\hline Cypris larvae, CI & 0.63 & 0.43 & 0.15 & 0.76 & 1.20 \\
\hline Sipunculida, ni & 0.48 & 1.87 & 0.00 & 0.00 & 0.00 \\
\hline Radiolaria, ni & 0.48 & 0.86 & 0.61 & 0.15 & 0.30 \\
\hline Petrolisthes megalopa, ni-D & 0.37 & 0.72 & 0.77 & 0.00 & 0.00 \\
\hline Echinolittorina peruviana (Lamarck), G & 0.30 & 0.57 & 0.00 & 0.15 & 0.45 \\
\hline Brachidontes granulata (Hanley), B & 0.30 & 0.00 & 0.15 & 0.61 & 0.45 \\
\hline Eurhomalea sp., B & 0.26 & 0.57 & 0.15 & 0.15 & 0.15 \\
\hline Phragmatopoma moerchi Kinberg, P & 0.26 & 0.00 & 0.15 & 0.76 & 0.15 \\
\hline Balanus laevis (Bruguière), CI & 0.22 & 0.14 & 0.15 & 0.15 & 0.45 \\
\hline Chironomidae, ni - I & 0.19 & 0.00 & 0.00 & 0.00 & 0.75 \\
\hline Egg capsules of Concholepas concholepas (Bruguière), G & 0.15 & 0.57 & 0.00 & 0.00 & 0.00 \\
\hline Other items ${ }^{\text {a }}$ (regional frequency $<0.15$ ) & 0.98 & 1.14 & 0.61 & 1.07 & 0.74 \\
\hline
\end{tabular}

cases, occurred as entire individuals, juveniles, or adults in the intestine of larger herbivores (urchins, keyhole limpets, and chitons). All of the remaining animal items (Table 2) appeared in lower frequencies, and the most important were mussels, bryozoans, hydrozoans, amphipods, decapods, snails, foraminifera, and nematodes, which, considered as adult and larval stages, presented a summed occurrence of $40.3 \%$.

Table 3 shows the biomass in gastric contents for a small sample of individuals per species, which, on average, ingested $87.1 \%$ (range: 55.0 to $97.8 \%$ ) of algae and $12.9 \%$ (range: 2.2 to $45 \%$ ) of animals. Notably, some small-sized species such as Scurria viridula, S. ceciliana, Siphonaria lessoni, and Lottia orbigny had a much higher proportion of animal bio- mass than larger species, although quantitatively smaller in absolute terms. In fact, the dry weight of herbivore individuals was positively correlated with the ingested biomass of algae (Spearman's $r=0.87, \mathrm{p}<$ $0.00001, \mathrm{n}=18$ ) and animals (Spearman's $\mathrm{r}=0.70, \mathrm{p}=$ $0.0013, \mathrm{n}=18$ ), i.e. larger herbivores eat more and the quantitative importance of animal consumption increases with herbivore size. On the other hand, herbivore weight was highly correlated with the ingested biomass per algal item (Spearman's $\mathrm{r}=0.86, \mathrm{p}<$ 0.00001, $\mathrm{n}=18$ ), but not per animal item (Spearman's $\mathrm{r}=0.31, \mathrm{p}=0.205, \mathrm{n}=18$ ), and this latter value was very high in more than a third of the species irrespective of their size. A 2-way Friedman test did not show significant differences between species $(\mathrm{Fr}=26.08, \mathrm{p}=$ 
Table 3. Biomass of algal and animal items in the gastric content of herbivore individuals, expressed as mg wet weight and percentage of total biomass. BPI: estimation of biomass per algal and animal item (see 'Materials and methods' for calculation details)

\begin{tabular}{|c|c|c|c|c|}
\hline \multirow[t]{2}{*}{ Species } & \multicolumn{2}{|c|}{$\longrightarrow$ Algae } & \multicolumn{2}{|c|}{ Animals } \\
\hline & Mean \pm SE $(\%)$ & BPI & Mean \pm SE $(\%)$ & BPI \\
\hline Acanthopleura echinata & $1812 \pm 390(95.8)$ & 226.8 & $79 \pm 47(4.2)$ & 39.5 \\
\hline Chiton cumingii & $30 \pm 13(80.5)$ & 10.0 & $7 \pm 5(19.5)$ & 8.6 \\
\hline Chiton granosus & $96 \pm 21(90.3)$ & 23.1 & $10 \pm 3(9.7)$ & 8.9 \\
\hline Enoplochiton niger & $1192 \pm 171(95.9)$ & 174.6 & $51 \pm 20(4.1)$ & 34.4 \\
\hline Fissurella costata & $228 \pm 164(97.8)$ & 39.0 & $5 \pm 4(2.2)$ & 10.8 \\
\hline Fissurella crassa & $338 \pm 131(87.2)$ & 47.0 & $50 \pm 27(12.8)$ & 33.2 \\
\hline Fissurella limbata & $130 \pm 28(94.9)$ & 17.0 & $7 \pm 2(5.1)$ & 3.9 \\
\hline Fissurella maxima & $1378 \pm 219(95.8)$ & 203.1 & $60 \pm 14(4.2)$ & 38.4 \\
\hline Fissurella picta & $1565 \pm 324(97.1)$ & 200.2 & $47 \pm 18(2.9)$ & 24.0 \\
\hline Lottia orbigny & $19 \pm 5(74.7)$ & 4.9 & $6 \pm 2(25.3)$ & 5.4 \\
\hline Loxechinus albus & $7948 \pm 2758(97.2)$ & 696.6 & $225 \pm 27(2.8)$ & 62.2 \\
\hline Scurria ceciliana & $20 \pm 13(57.6)$ & 6.6 & $15 \pm 6(42.4)$ & 38.8 \\
\hline Scurria variabilis & $15 \pm 1(91.7)$ & 3.2 & $1 \pm 0.3(8.3)$ & 3.9 \\
\hline Scurria viridula & $37 \pm 14(55.0)$ & 9.6 & $30 \pm 14(45.0)$ & 54.6 \\
\hline Siphonaria lessoni & $39 \pm 18(74.4)$ & 9.5 & $13 \pm 12(25.6)$ & 43.7 \\
\hline Taliepus dentatus & $149 \pm 2(94.0)$ & 23.3 & $10 \pm 3(6.0)$ & 5.6 \\
\hline Tegula atra & $394 \pm 131(91.0)$ & 86.2 & $39 \pm 12(9.0)$ & 57.1 \\
\hline Tetrapygus niger & $3278 \pm 1277(97.6)$ & 415.3 & $80 \pm 48(2.4)$ & 2.4 \\
\hline
\end{tabular}

Table 4. Quantitative descriptors characterizing apparent IG predator-IG prey pairwise interactions among herbivores of northern Chile (for full binomial names see Table 1). Some values involving Scurria sp. were omitted due to its unresolved specific status. Ov: mean $( \pm \mathrm{SE})$ diet overlap; BR: body size ratio IG predator/IG prey calculated from mean dry biomass (BRb) and mean maximum length $(\mathrm{BRl})$; BPr: mean $( \pm \mathrm{SE})$ niche breadth of IG predator; NPr: total number of IG predator individuals; OFPy: occurrence frequency (\%) of IG prey

\begin{tabular}{|c|c|c|c|c|c|c|}
\hline IG predator-IG prey & $\mathrm{Ov}$ & $\mathrm{BRb}$ & $\mathrm{BRl}$ & $\mathrm{BPr}$ & NPr & OFPy \\
\hline A. echinata-T. atra & 0.61 & 3.10 & 4.99 & $12.30 \pm 1.52$ & 166 & 1.20 \\
\hline A. echinata-S. araucana & 0.44 & 62.27 & 8.50 & $"$ & $"$ & 0.60 \\
\hline E. niger-L. orbigny & 0.11 & 57.82 & 7.05 & $11.55 \pm 0.98$ & 268 & 0.37 \\
\hline E. niger-Scurria sp. & - & - & - & $"$ & $"$ & 0.75 \\
\hline E. niger-T. niger & 0.54 & 1.40 & 2.31 & $"$ & $"$ & 0.37 \\
\hline E. niger-T. atra & 0.54 & 3.09 & 4.54 & $"$ & $"$ & 0.75 \\
\hline E. niger-S. ceciliana & 0.48 & 227.14 & 15.12 & $"$ & $"$ & 0.75 \\
\hline E. niger-S. variabilis & 0.56 & 138.26 & 8.90 & $"$ & $"$ & 0.37 \\
\hline F. crassa-F. limbata & 0.79 & 0.75 & 0.97 & $10.07 \pm 2.20$ & 194 & 1.55 \\
\hline F. crassa-F. maxima & 0.74 & 0.59 & 0.88 & $"$ & $"$ & 1.03 \\
\hline F. crassa-O marginata & 0.51 & 411.15 & 4.61 & $"$ & $"$ & 0.52 \\
\hline F. crassa-T. atra & 0.41 & 0.91 & 1.70 & $"$ & $"$ & 0.52 \\
\hline F. limbata-S. ceciliana & 0.47 & 94.57 & 5.81 & $12.89 \pm 1.54$ & 142 & 0.70 \\
\hline F. limbata-D. nigerrima & 0.48 & 57.56 & 4.77 & $"$ & $"$ & 1.41 \\
\hline F. limbata-T. atra & 0.60 & 1.21 & 1.75 & $"$ & $"$ & 1.41 \\
\hline F. limbata-Scurria sp. & - & - & - & $"$ & $"$ & 0.70 \\
\hline F. limbata-O. marginata & 0.58 & 547.1 & 4.73 & $"$ & $"$ & 0.70 \\
\hline F. maxima-P. niger & 0.46 & 42.69 & 6.04 & $11.86 \pm 1.28$ & 181 & 1.10 \\
\hline F. maxima-C. cumingii & 0.67 & 11.02 & 1.43 & " & " & 0.55 \\
\hline L. albus-S. variabilis & 0.39 & 119.56 & 4.06 & $17.53 \pm 1.77$ & 39 & 2.56 \\
\hline L. albus-S. ceciliana & 0.26 & 190.97 & 6.90 & " & $"$ & 2.56 \\
\hline L. albus-T. atra & 0.47 & 2.52 & 2.06 & $"$ & $"$ & 7.69 \\
\hline L. albus-T. niger & 0.63 & 1.21 & 1.05 & $"$ & $"$ & 2.56 \\
\hline T. dentatus-T. atra & 0.44 & 0.22 & 1.34 & 9.72 & 10 & 10.00 \\
\hline T. niger-T. atra & 0.43 & 2.08 & 1.95 & $12.81 \pm 0.04$ & 251 & 1.59 \\
\hline T. niger-Scurria sp. & - & - & - & 4 & " & 0.40 \\
\hline T. niger-S. ceciliana & 0.31 & 157.15 & 6.53 & $"$ & $"$ & 1.20 \\
\hline T. niger-D. nigerrima & 0.41 & 98.39 & 5.36 & $"$ & $"$ & 0.40 \\
\hline T. niger-P. niger & 0.33 & 58.02 & 6.15 & $"$ & $"$ & 0.40 \\
\hline
\end{tabular}


0.0731, $\mathrm{df}=17$ ) or between algal and animal biomass per item $(\mathrm{Fr}=3.56, \mathrm{p}=0.0593, \mathrm{df}=1)$, but we note that probability values are marginal and ranking procedures diminish the differences among values. Thus, the above results should be considered preliminary and need support from a larger sample. Notwithstanding, Table 3 confirms the consistency of animal consumption by herbivores, and clearly shows that some species may consume animal items with similar or greater intensity than algal items.

\section{Apparent intraguild predation}

Herbivore consumers ingested almost exclusively heterospecific herbivore prey, as the consumption of conspecifics occurred only once in 2671 cases (0.03\%; a juvenile black urchin Tetrapygus niger); this behavior was excluded from subsequent analyses due to its extremely low occurrence. Thus, we identified a total of 29 pairs of interspecific herbivore-herbivore interactions (Table 4) involving 19 species, 8 of them appearing as IG predators and 11 as IG prey, although 3 species were recorded in both categories (Fissurella limbata, F. maxima, T. niger). Among IG prey, Scurria sp. could not be identified with the available diagnostic characters (Espoz et al. 2004), which forced us to omit some descriptors for this IG prey in Table 4 (we provisionally treated this species as different from those listed in Table 1). The 29 IG predator-IG prey pairs shared food resources to different extents, with mean dietary overlaps ranging from 0.11 to 0.79 , and an average $( \pm \mathrm{SE})$ dietary overlap of $0.49 \pm 0.03$ for all pairs (Table 4). Six IG predator-IG prey pairs had a mean dietary overlap $\geq 0.6$, and 4 of these cases involved keyhole limpets (F. crassa, F. limbata, or $F$. maxima). Notably, the 29 interactions were all taxonomically asymmetrical (no reciprocal predation), and only $3(10.3 \%)$ occurred among taxonomically related species (keyhole limpets: F. crassa on F. limbata and F. maxima; sea urchins: Loxechinus albus on T. niger). All IG predators (Table 4) were generalist consumers with a large dietary breadth (considering their whole resource spectrum), and only 5 of them (Enoplochiton niger, F. crassa, F. limbata, L. albus, and T. niger) gave origin to $24(>80 \%)$ of the pairwise interactions.

Adult body size ratios (IG predator/IG prey) were largely asymmetrical both in biomass and length (Table 4), favoring IG predators, with a few exceptions (mainly involving Fissurella crassa). Length ratio was a better descriptor of size asymmetry, as biomass ratio produced extremely high values for large IG predators with shells or skeletons (e.g. fissurellids, urchins) eating small IG prey such as the limpets Scurria spp. and the shell-less sea slug Onchidella marginata. On the other hand, IG prey showed relatively low occurrence frequencies, and the 2 interactions with the highest prey frequencies (Taliepus dentatus on Tegula atra, Loxechinus albus on T. atra) involved the 2 IG predators with the smallest sample size, suggesting that their importance may be overestimated.

The above data were separated to represent IGP webs (omnivore links) by community (seasonal data pooled), with the respective occurrence frequencies of IG prey (Fig. 2; links to basal algal species were omitted for clarity). Among all IG predators, only 2 (the chi-

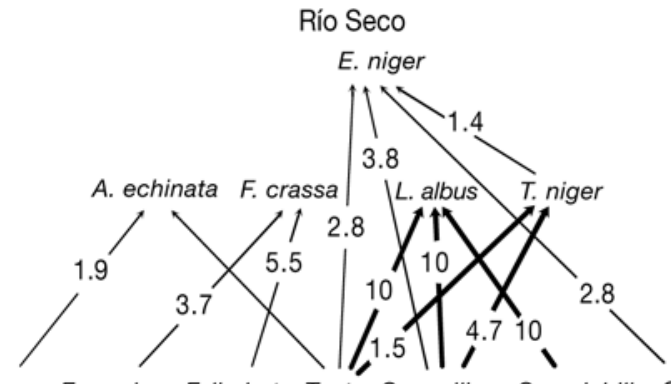

S. araucana F. maxima F. limbata T. atra S. ceciliana S. variabilis Scurria sp.

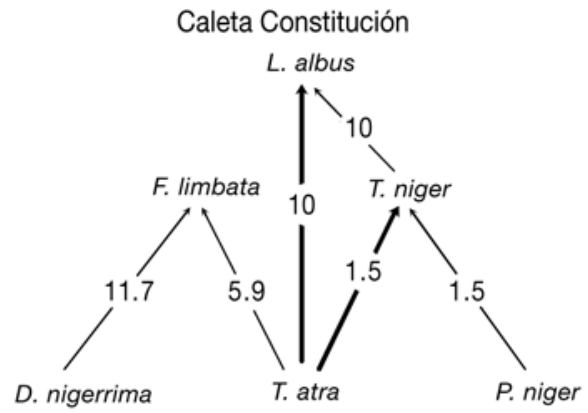

Lagunillas

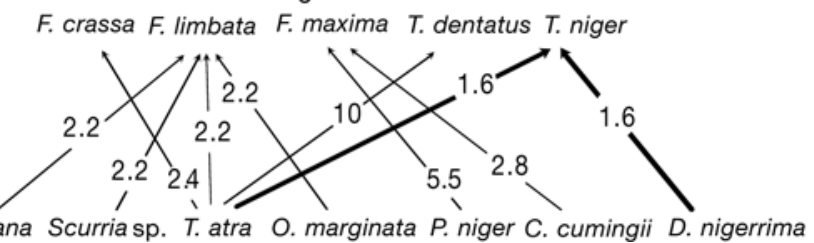

Fig. 2. Intraguild predation subwebs (arrows point to intraguild predators) detected in the 4 study communities: intraguild predation upon juvenile prey only (thin arrows) or both juvenile and adult prey (thick arrows). Numbers on arrows: dietary occurrence frequency $(\%)$ of intraguild prey. For full binomial names see Table 1 
ton Enoplochiton niger in RIO and the urchin Loxechinus albus in (CO) appeared at a higher trophic position generating 3-link food chains. In all communities, IG predators were all large-sized species and ate mainly juvenile or small-sized individuals. The proportion of pairwise interactions per community in which IG predators ate only juvenile IG prey was $58.3 \%$ in RIO, $66.7 \%$ in CCO, $50 \%$ in CAN, and $80 \%$ in LAG. In addition, from dietary overlap values in Table 4 , it follows that each IG predator shared several resources with each of its IG prey, and thus closed loop omnivory was the rule in all food webs represented in Fig. 2.

\section{DISCUSSION}

\section{Potential for omnivory}

The consumption of animals by rocky intertidal herbivores in northern Chile seems a common and widespread phenomenon, and its high frequency justifies a more thorough evaluation of its ecological significance and strength. We highlight the great relative importance of barnacles, particularly the species Jehlius cirratus and Notochthamalus scabrosus, both of which are common and dominant in northern Chile (Camus \& Lagos 1996, Lagos et al. 2005), suggesting that their consumption could be related, in part, to their high abundance and frequency of occurrence on rocky substrata. In contrast, the consumption of a wide variety of items, including planktonic organisms, larval stages, chironomid insects, egg capsules of carnivores, and even some carnivore snails and crabs, was infrequent and diffuse. Likely, the ingestion of such miscellaneous items is a casual phenomenon that would hardly be a source of important indirect effects. In this regard, however, the recurrent consumption of sessile animals, such as mussels and barnacles, has the potential to greatly affect space occupancy patterns, and deserves more attention in future studies. In the same terms, the frequent ingestion of other sessile organisms, such as bryozoans and hydrozoans, could be less important because of their small size, although (as with barnacles and mussels) they cannot be ignored as a potential food source for herbivores. Regardless of interaction strength, nonetheless, the sole existence of true omnivory would be highly significant in autoecological terms.

The potential for omnivory was high and positively related with the body mass of herbivores, as larger species consumed a wider spectrum of food resources and a higher proportion and biomass of animal items. In particular, large chitons, keyhole limpets and urchins appear as strong candidates to display omnivory at least as an opportunistic strategy, and their joint effect on animal prey may not be negligible. However, smaller species should not be underestimated, as some of them may ingest animals in higher proportion than larger ones, and others may show lower consumption but have very high densities in the field. Thus, the ingestion of animals by the whole herbivore assemblage has the potential to generate community-wide effects involving species' abundances and energy flows, which may be investigated in the same way as for algal prey (e.g. Sala \& Graham 2002).

None of the herbivores studied in this work have been assessed with respect to the digestion and assimilation of animal food, probably because they have always been treated as herbivores. Nonetheless, we suggest that our view of intertidal consumers on Chilean rocky shores needs a reappraisal from an energetic and food web perspective, noting that true omnivory and carnivory behaviors have been well documented in urchins (e.g. Hughes et al. 2005), chitons (e.g. Latyshev et al. 2004), and fissurellids (e.g. Grall et al. 2006) from other regions. In particular, the consumption of animals by Chilean fissurellids such as Fissurella crassa and F. maxima has long been recognized (Santelices \& Correa 1985, Santelices et al. 1986, Osorio et al. 1988), and our data confirm that this is a consistent phenomenon. For instance, F. picta in southern Chile consumes a nearly constant proportion of 30 to $35 \%$ of invertebrates throughout the year (López et al. 2003), very similar to our records in northern Chile $(\sim 30 \%)$ and to those observed in some true omnivores on other coasts (e.g. Cannicci et al. 2002). In fact, Fissurella species are efficient in consuming rough and hard materials (Santelices et al. 1986, Osorio et al. 1988), and exhibit a high capability to discriminate and select food items (Franz 1990a,b), but, in some cases, they cannot digest cellulose and agar (Ward 1966), suggesting some constraints to maintaining a strictly herbivorous diet. In this context, we recently performed physiological assays on 3 of our study species (F. maxima, F. picta, Chiton granosus) fed with mussel tissue, finding proteolytic digestion and assimilation of food to different extents (Camus et al. unpubl. data), although more detailed studies must be conducted for confirmation. Intertidal herbivores may thus be more complex consumers than previously thought, and an active search for true omnivory behavior among these species would help to establish their functional role with accuracy.

On general grounds, recent assessments of aquatic and terrestrial systems (e.g. Beaudoin et al. 2001, Link 2002, Arim \& Marquet 2004, Vadas 2004, Bode et al. 2006, Thompson et al. 2007; but see Williams \& Martinez 2004), suggest that omnivory is common in real food webs. In this respect, all members of the herbivore trophic level in this study consumed prey at more than 
one trophic level, and trophic omnivory has been shown to be frequent among other intertidal consumers such as fish (e.g. Muñoz \& Ojeda 1997), birds (e.g. Hori \& Noda 2001), and non-herbivorous invertebrates (e.g. Navarrete et al. 2000). Thus, the prevalence of omnivory could be high across the whole rocky intertidal food web, independent of its significance with regard to food web stability or top-down and bottom-up cascading effects.

\section{Apparent intraguild predation}

Our data suggest that, even in the absence of true omnivory, indirect effects derived from apparent IGP could be potentially important among herbivore populations. However, if some of our study species were true omnivores and/or true IG predators, both their role and trophic position should be entirely reconsidered. A higher incidence of IGP may have several implications for the structure and stability of intertidal food webs (Arim \& Marquet 2004), derived from the introduction of longer food chains, new links, and closed omnivore loops. For instance, each of the 8 IG predators were connected with at least 83 food items (including IG prey) of varying trophic positions, and they were in turn consumed by a high number of top and intermediate carnivores, such as gastropods, crabs, seastars, fishes, birds, otters, and rodents (e.g. Soto 1996, Muñoz \& Ojeda 1997, 1998, Fariña et al. 2003). Conversely, our ongoing research on the northern Chilean food web shows that keystone predators, such as the carnivorous sunstar Heliaster helianthus (Lamarck), consume all our IG predators, except Taliepus dentatus (Camus et al. unpubl. data). Thus, the studied IG predators are highly connected species, strongly linked to basal organisms, participating in a high number of closed loops involving other herbivores, and linked to a number of higher level consumers including top and intermediate predators. In addition, IG predators are involved in the interplay between bottom-up and top-down processes, when food web directionality becomes a crucial aspect (Borer et al. 2002). Key herbivores such as Loxechinus albus and most Fissurella species are heavily collected by coastal food-gatherers (Oliva \& Castilla 1986, Fernández \& Castilla 2005), and reduction of that pressure might not only increase their connectivity, but also trigger structural changes in the food web (e.g. see Vasas et al. 2007). On the other hand, the high connectivity of the studied species is partially an expected byproduct of more intensive samplings and diet analyses (as pointed out by Polis 1991 and Link 2002), but the importance of the contributed links will depend on their nature and strength. Most IG predator-IG prey interactions showed quantitatively low importance in terms of consumption frequency of IG prey, as compared, for instance, with the consumption of barnacles. However, weak links could promote community stability (McCann et al. 1998, Neutel et al. 2002), and any IG predator-IG prey link would be important if it turns out to be a real pathway for energy and nutrient acquisition. In this context, 2 of our results remain intriguing: the complete taxonomical asymmetry of IG predator-IG prey interactions and the absence of self-consumption. Such a pattern was not expected to arise from purely incidental consumption by herbivores, where at least part of their ingested prey should be incorporated at random, including conspecific juveniles. The above suggests that apparent IGP may not be a side-effect of grazing, and thus leaves the possibility open that some IG predators may discriminate among IG prey, avoiding the consumption of conspecifics, while they clearly do not avoid heterospecifics. (However, we do not suggest that IG predators pursue, attack, or capture their prey as do some true carnivorous predators.)

Additionally, as observed in some lotic systems (Lancaster et al. 2005), it is possible that herbivores are forced to use or even select animal prey during periods of strong resource limitation, increasing the incidence of polyphagy and apparent IGP. In this regard, our study period included the complete development of a weak El Niño event (August 2004 to March 2005; CPC 2007), when algal resources are likely to diminish due to nutrient limitation (Thiel et al. 2007). However, polyphagy and apparent IGP occurred at all study sites, although 2 of them (CCO, LAG) could sustain a higher nutrient loading and algal productivity due to the persistent influence of upwelling, even during El Niño periods (Thiel et al. 2007). Therefore, polyphagy and apparent IGP may be part of the normal feeding behavior of herbivores, rather than a consequence of resource limitation.

For our study communities, we should conclude that the apparent IGP itself is probably weak in terms of per capita effects, but it is relatively common and potentially significant in the face of true omnivory. In such a context, eating at more than one trophic level or ingesting plants and animals appear to be necessary but not sufficient conditions to define omnivory, as they do not clarify the distinction between eating and feeding. We also note that the high connectedness and trophic diversity of the studied assemblage were, as envisaged by Polis (1991), inevitable by-products of improving the resolution of dietary analyses and the intensity of samplings (see also Hall \& Raffaelli 1991, Link 2002). Thus, our data show that rocky intertidal food webs may indeed have a high degree of connectivity, long food chains, and a widespread occurrence 
of polyphagy and loops, which are not necessarily different or more complex than those of other marine or non-marine systems (see Dunne et al. 2004, Thompson et al. 2007). In addition, the studied herbivores seem far from being equivalent members of a single trophic level, and we would clearly misjudge their role in bottom-up processes by simply considering them primary consumers.

Acknowledgements. This study was funded by CONICYT, Chile (Project FONDECYT No. 1040425). We are grateful to P. E. Neill and 3 anonymous reviewers for their comments and suggestions, and to A. Navarrete, D. López, and K. Daroch for field and laboratory assistance.

\section{LITERATURE CITED}

Arim M, Marquet PA (2004) Intraguild predation: a widespread interaction related to species biology. Ecol Lett 7: 557-564

Beaudoin CP, Prepas EE, Tonn WM, Wassenaar LI, Kotak BG (2001) A stable carbon and nitrogen isotope study of lake food webs in Canada's boreal plain. Freshw Biol 46: 465-477

Bode A, Alvarez-Ossorio MT, Varela M (2006) Phytoplankton and macrophyte contributions to littoral food webs in the Galician upwelling estimated from stable isotopes. Mar Ecol Prog Ser 318:89-102

Borer ET, Anderson K, Blanchette CA, Broitman B, Cooper SD, Halpern BS (2002) Topological approaches to food web analysis: a few modifications may improve our insights. Oikos 99:397-401

Briscoe CS, Sebens KP (1988) Omnivory in Strongylocentrotus droebachiensis (Muller) (Echinodermata: Echinoidea): predation on subtidal mussels. J Exp Mar Biol Ecol 115: $1-24$

Camus PA, Lagos N (1996) Patrones de variación espaciotemporal del reclutamiento en dos ensambles de especies intermareales sésiles del norte de Chile. Rev Chil Hist Nat 69:193-204

Cannicci S, Gomei M, Boddi B, Vannini M (2002) Feeding habits and natural diet of the inntertidal crab Pachygrapsus marmoratus: Opportunistic browser or selective feeder? Estuar Coast Shelf Sci 54:983-1001

CPC (Climate Prediction Center, NOAA/National Weather Service) (2007) ENSO years. Available at: www.cpc.ncep. noaa.gov/products/analysis_monitoring/ensostuff/ensoye ars.shtml. Accessed on 12 March 2007

Dunne JA, Williams RJ, Martinez ND (2004) Network structure and robustness of marine food webs. Mar Ecol Prog Ser 273:291-302

Espoz C, Lindberg DR, Castilla JC, Simison WB (2004) Los patelogastrópodos intermareales de Chile y Perú. Rev Chil Hist Nat 77:257-283

> Fariña JM, Castilla JC, Ojeda FP (2003) The 'idiosyncratic' effect of a 'sentinel' species on contaminated rocky intertidal communitites. Ecol Appl 13:1533-1552

Feinsinger P, Spears EE, Poole RW (1981) A simple measure of niche breadth. Ecology 62:27-32

Fernández M, Castilla JC (2005) Marine conservation in Chile: historical perspective, lessons, and challenges. Conserv Biol 19:1752-1762

Franz CJ (1990a) Feeding patterns of Fissurella species on Isla de Margarita, Venezuela: use of radulae and food passage rates. J Molluscan Stud 56:23-35
Franz CJ (1990b) Differential algal consumption by three species of Fissurella (Mollusca: Gastropoda) at Isla de Margarita, Venezuela. Biol Bull 46:735-748

> Grall J, Le Loc'h F, Guyonnet B, Riera P (2006) Community structure and food web based on stable isotopes $\left(\delta^{15} \mathrm{~N}\right.$ and $\delta^{13} \mathrm{C}$ ) analysis of a north eastern Atlantic maerl bed. J Exp Mar Biol Ecol 338:1-15

Hall SJ, Raffaelli D (1991) Food-web patterns: lessons from a species-rich web. J Anim Ecol 60:823-842

Hori M, Noda T (2001) Spatio-temporal variation of avian foraging in the rocky intertidal food web. J Anim Ecol 70: 122-137

> Hughes AD, Catarino AI, Kelly MS, Barnes DKA, Black KD (2005) Gonad fatty acids and trophic interactions of the echinoid Psammechinus miliaris. Mar Ecol Prog Ser 305: $101-111$

Lagos NA, Navarrete SA, Véliz F, Masuero A, Castilla JC (2005) Meso-scale spatial variation in settlement and recruitment of intertidal barnacles along central Chile. Mar Ecol Prog Ser 290:165-178

Lancaster J, Bradley DC, Hogan A, Waldron S (2005) Intraguild omnivory in predatory stream systems. J Anim Ecol 74:619-629

Latyshev NA, Khardin AS, Kasyanov SP, Ivanova MB (2004) A study in the feeding ecology of chitons using analysis of gut contents and fatty acid markers. J Molluscan Stud 70: $225-230$

Levins R (1968) Evolution in changing environments: some theoretical explorations. Princeton University Press, Princeton, NJ

Link J (2002) Does food web theory work for marine ecosystems? Mar Ecol Prog Ser 230:1-9

López DA, González ML, Pérez MC (2003) Feeding and growth in the keyhole limpet, Fissurella picta (Gmelin, 1791). J Shellfish Res 22:165-169

> Lubchenco J (1978) Plant species diversity in a marine intertidal community: importance of herbivore food preference and algal competitive abilities. Am Nat 112:23-39

Lubchenco J (1979) Consumer terms and concepts. Am Nat 113:315-317

> Lubchenco J, Gaines SD (1981) A unified approach to marine plant-herbivore interactions. I. Populations and communities. Annu Rev Ecol Syst 12:405-437

McCann K, Hastings A, Huxel GR (1998) Weak trophic interactions and the balance of nature. Nature 395:794-798

> Muñoz AA, Ojeda FP (1997) Feeding ecology and guild structure of a rocky intertidal fish assemblage of Central Chile. Environ Biol Fishes 49:471-479

Muñoz AA, Ojeda FP (1998) Guild structure of carnivorous intertidal fishes of the Chilean coast: implications of ontogenetic dietary shifts. Oecologia 114:563-573

Navarrete SA, Menge BA, Daley BA (2000) Species interactions in intertidal food webs: prey or predation regulation of intermediate predators? Ecology 81:2264-2277

> Neutel AM, Heesterbeek JAP, de Ruiter PC (2002) Stability in real food webs: weak links in long loops. Science 296: 1120-1123

Oliva D, Castilla JC (1986) The effect of human exclusion on the population structure of key-hole limpets Fissurella crassa and F. limbata on the coast of central Chile. PSZNI: Mar Ecol 7:202-217

Omori K, Kikutani Y, Irawan B, Goda Y (2006) Size-dependent intraguild reciprocal predation between Helice tridens De Haan and H. japonica Sakai and Yatsuzuka (Decapoda: Grapsidae) as analyzed in field experiments. J Crustac Biol 26:148-153

Osorio C, Ramírez ME, Salgado J (1988) Gastric contents of 
Fissurella maxima (Mollusca: Archaeogastropoda) at Los Vilos, Chile. Veliger 30:347-350

Pianka ER (1973) The structure of lizard communities. Annu Rev Ecol Syst 4:53-74

Pimm SL, Lawton JH (1978) On feeding on more than one trophic level. Nature 275:542-544

Polis GA (1991) Complex trophic interactions in deserts: an empirical critique to food-web theory. Am Nat 138: $123-155$

Polis GA, Holt RD (1992) Intraguild predation: the dynamics of complex interactions. Trends Ecol Evol 7:151-155

Polis GA, Myers CA, Holt RD (1989) The ecology and evolution of intraguild predation: potential competitors that eat each other. Annu Rev Ecol Syst 20:297-330

Sala E, Graham MH (2002) Community-wide distribution of predator-prey interaction strength in kelp forests. Proc Natl Acad Sci USA 99:3678-3683

Santelices B, Correa JA (1985) Differential survival of macroalgae to digestion by intertidal herbivore molluscs. J Exp Mar Biol Ecol 88:183-191

Santelices B, Vásquez J, Meneses I (1986) Patrones de distribución y dietas de un gremio de moluscos herbívoros en hábitats intermareales expuestos de Chile central. In: Santelices B (ed) Usos y funciones ecológicas de las algas marinas bentónicas. Monografías Biológicas 4, P. Universidad Católica de Chile, Santiago, p 147-175

Soto RE (1996) Estructura gremial de un ensamble de depredadores de la zona intermareal rocosa en Chile central. Invest Mar Valparaiso 24:97-105

Sprules WG, Bowerman JE (1988) Omnivory and food chain length in zooplankton food webs. Ecology 69:418-426

Editorial responsibility: Laura Airoldi,

Ravenna, Italy
Thiel M, Macaya E, Acuña E, Arntz W and others (2007) The Humboldt Current System of northern-central Chile: oceanographic processes, ecological interactions and socioeconomic feedback. Oceanogr Mar Biol Annu Rev 45: 195-344

Thompson RM, Hemberg M, Starzomski BM, Shurin JB (2007) Trophic levels and trophic tangles: the prevalence of omnivory in real food webs. Ecology 88:612-617

Vadas RL Jr (1990) The importance of omnivory and predator regulation of prey in freshwater fish assemblages of North America. Environ Biol Fishes 27:285-302

Vasas V, Lancelot C, Rousseau V, Jordán F (2007) Eutrophication and overfishing in temperate nearshore pelagic food webs: a network perspective. Mar Ecol Prog Ser 336: $1-14$

Vásquez JA, Camus PA, Ojeda FP (1998) Diversidad, estructura y funcionamiento de ecosistemas litorales rocosos del norte de Chile. Rev Chil Hist Nat 71:479-499

Ward J (1966) Feeding, digestion, and histology of the digestive tract in the keyhole limpet Fissurella barbadensis Gmelin. Bull Mar Sci 16:668-683

Williams RJ, Martinez ND (2004) Limits to trophic levels and omnivory in complex food webs: theory and data. Am Nat 163:458-468

> Winemiller KO, Pianka ER, Vitt LJ, Joern A (2001) Food web laws or niche theory? Six independent empirical tests. Am Nat 158:193-199

Wootton JT (1993) Indirect effects and habitat use in an intertidal community: interaction chains and interaction modifications. Am Nat 141:71-89

Yodzis P (1984) How rare is omnivory? Ecology 65:321-323

Submitted: June 21, 2007; Accepted: January 25, 2008

Proofs received from author(s): May 23, 2008 